${ }^{6}$ Goldberg E, Winter S T, Better O S, Berger A. Transient neonatal hyperparathyroidism associated with maternal hypoparathyroidism. Isr J Med Sci 1976; 12: 199-201.

7 Tomlinson S, Hendy G N, O'Riordan J L H. A simplified assessment of response to parathyroid hormone in hypoparathyroid patients. Lancet 1976; i: 62-4.
Correspondence to Dr E J Glass, Paediatric Department, Simpson Memorial Maternity Pavilion, Lauriston Place, Edinburgh EH3 9EF.

Received 15 July 1980

\title{
Effects of water supplementation on physiological jaundice in breast-fed babies
}

\author{
MANOEL DE CARVALHO, MICHAEL HALL, AND DAVID HARVEY
}

Queen Charlotte's Maternity Hospital, London

SUMMARY The effect of water supplementation in normal, term, breast-fed babies with physiological jaundice was studied. Water supplementation was given to 120 babies and 55 received no extra fluids. There was no significant difference between the two groups when peak serum bilirubin levels and incidence of phototherapy were compared.

Although there is conflicting evidence about the incidence of hyperbilirubinaemia in bottle- and breast-fed newborn infants, recent reports support the view that jaundice occurs more often, and with relatively higher serum bilirubin concentrations, in

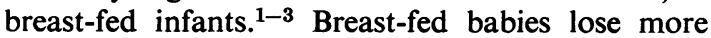
weight in the first few days of life and, in the past, this was thought to be related to the presence of jaundice. ${ }^{4}$ It is therefore common to give water supplements to breast-fed babies in an attempt to reduce the severity of jaundice. However, the use of water supplements may interfere with both the establishment and duration of breast-feeding. ${ }^{5}$ The present study was undertaken to determine the effect of water supplementation on the course of physiological jaundice in breast-fed babies.

\section{Patients and methods}

Between 1 June and 31 November 1979 infants in the postnatal wards at this hospital were placed in one of two groups. In group $1(n=55$, one ward) breast-fed babies received no fluid supplementation from birth, and in group $2(n=120$, three wards) water supplementation was given ad libitum at the end of each breast feed. All babies were fed on demand and received the first feed within 3 hours of birth. Only normal term babies whose birthweight was $2.5 \mathrm{~kg}$ or more were included.
Babies who were considered to have physiological jaundice entered the study if the serum bilirubin concentration reached $200 \mu \mathrm{mol} / \mathrm{l}(11.7 \mathrm{mg} / 100 \mathrm{ml})$. Phototherapy was started at a serum bilirubin level of $320 \mu \mathrm{mol} / 1(18.7 \mathrm{mg} / 100 \mathrm{ml})$. Any baby with rhesus disease, hypothyroidism, or congenital infection was excluded. Any baby with a definite diagnosis of $\mathrm{ABO}$ haemolytic disease was excluded, but it is possible that a few babies with very mild disease were included because of the difficulty in making the diagnosis.

All blood specimens were taken daily by heelprick and the serum bilirubin concentration was measured using an American optical bilirubinometer. ${ }^{6}$

There was no significant difference between the groups for number of deliveries by forceps, caesarean section, or ventous extraction. There were 8 breech deliveries in group 2 and none in group 1.

\section{Results}

As can be seen from the Table, there was no

Table Data $(S D)$ for the two groups of infants

\begin{tabular}{|c|c|c|c|}
\hline & $\begin{array}{l}\text { Group } I(n=55) \\
\text { (no supplement) }\end{array}$ & $\begin{array}{l}\text { Group } 2(n=120) \\
\text { (water } \\
\text { supplement) }\end{array}$ & $\begin{array}{l}\text { Significance } \\
\text { of different } \\
\text { incidence }\end{array}$ \\
\hline $\begin{array}{l}\text { Mean birthweight (g) } \\
\text { Mean lowest }\end{array}$ & 3249 (397) & $3372(411)$ & NS $^{*}$ \\
\hline $\begin{array}{l}\text { weight (g) } \\
\text { Mean weight }\end{array}$ & 3034 (386) & $3181(396)$ & $P<0.05$ \\
\hline $\begin{array}{l}\text { loss (g) } \\
\text { Mean peak serum }\end{array}$ & 215 (116) & $191(91)$ & $\mathrm{NS}^{*}$ \\
\hline bilirubin $(\mu \mathrm{mol} / \mathrm{l})$ & $263 \cdot 5$ & 260 & NS \\
\hline $\begin{array}{l}\text { peak bilirubin (days) } \\
\text { Number receiving }\end{array}$ & $4 \cdot 62$ & $4 \cdot 64$ & NS \\
\hline phototherapy & 8 & 11 & NS $\dagger$ \\
\hline
\end{tabular}

Conversion: SI to traditional units-bilirubin: $1 \mu \mathrm{mol} / 1 \approx 0.058$ $\mathrm{mg} / 100 \mathrm{ml}$.

*Student's $t$ test, $\dagger \chi^{2}, \mathrm{NS}=$ not significant. 
statistically significant difference between the two groups for either peak serum bilirubin, or the number of babies receiving phototherapy.

\section{Discussion}

Hyperbilirubinaemia is common in breast-fed babies; the incidence may be as high as $25 \%^{3}{ }^{3}$ Although the use of water supplementation with an aim of reducing the serum bilirubin concentrations in such babies is widespread, we did not have any clear evidence of its efficacy. This study failed to demonstrate that water supplementation in normal, term, breast-fed babies with physiological jaundice reduced serum bilirubin concentrations or the requirement for phototherapy compared with a control group.

As expected, babies who received water supplementation lost less weight, although the difference is not significant. The relationship between weight loss and neonatal jaundice is controversial ${ }^{\mathbf{1}}$; our own figures suggest no correlation.

There are several potential hazards in the administration of unnecessary supplements to breast-fed babies. ${ }^{5}$ The establishment of breast-feeding may be impaired because of the different suckling mechanism; the frequency of demand feeds may be reduced thus inhibiting the process of lactation; maternal confidence may be undermined leading to stopping breast feeding early. ${ }^{7}$
It is our feeling that in view of the possible detrimental eifects of water supplementation to breast-fed babies this 'innocent' common practice requires further investigation.

\section{References}

1 Dahms B B, Krauss A N, Gartner L M, Klain D B, Soodalter J, Auld P A M. Breast-feeding and serum bilirubin values during the first four days of life. $J$ Pediatr 1973; 83: 1049-54.

2 Fisher Q, Cohen M I, Curda L, McNamara H. Jaundice and breast-feeding among Alaskan eskimo newborn. Am J Dis Child 1978;132: 859-61.

3 Wood B, Culley P, Roginski C, Powell J, Waterhouse J. Factors affecting neonatal jaundice. Arch Dis Child 1979; 54: 111-5.

4 Hubbell J P, Jr, Drorbaugh J E, Rudolph A J, Auld P A M, Cherry R B, Smith C A. 'Early' versus 'late' feeding of infants of diabetic mothers. $N$ Engl J Med 1961; 265: 835-7.

5 Berg T A. Nursing the newborn. Semin Perinatol 1979; 3: 241-8.

6 Williams R A, Pitts L, Weinerth J L, Dimmette R M. Clinical laboratory evaluation of the American optical bilirubinometer. J Pediatr 1971 ; 79: 671-4.

7 Laurance B L, Creery D, Stroud E. Feeding babies in the 70’s. Nurs Times 1977; 73: Supplement, 1-4.

Correspondence to $\mathrm{Dr}$ M A Hall, Southampton General Hospital, Centre Block, Room CG 56, Tremona Road, Southampton SO9 4XY.

Received 22 September 1980 